\title{
THE PRODUCTION OF DIARRHOEA IN BABY RABBITS BY THE ORAL ADMINISTRATION OF CELL-FREE PRE- PARATIONS OF ENTEROPATHOGENIC ESCHERICHIA COLI AND VIBRIO CHOLERAE: THE EFFECT OF ANTI- SERA
}

H. Williams Smith

Houghton Poultry Research Station, Houghton, Huntingdon

\section{Plate XVII}

SINCE the initial investigations of Dutta, Panse and Kulkarni (1959), baby rabbits have been used fairly extensively in studying the diarrhoeaproducing effect of orally administered cell-free products of Vibrio cholerae. Essentially the same technique, but with piglets, has been employed by Kohler (1968) and Smith and Gyles (1970a) in studying porcine enteropathogenic strains of Escherichia coli. Exploiting the fact that the enterotoxin produced by these porcine strains is controlled by a transmissible plasmid designated Ent (Smith and Halls, 1968), Smith and Gyles (1970a) were able to compare materials from strains that differed only according to whether they were Ent ${ }^{+}$ or Ent ${ }^{-}$. The value of such a well-controlled system became apparent when it was noted that under some conditions material from an Ent ${ }^{-}$strain could cause diarrhoea. Recently Smith and Linggood (1971) transmitted an Ent plasmid from a human enteropathogenic strain of $E$. coli to $E$. coli $\mathrm{K}_{12} \mathrm{~F}^{-}$. Because the enterotoxin produced by this strain, like that produced by most other human enteropathogenic strains, is not active on ligated pig intestine, but is active on ligated rabbit intestine, it was decided to determine its effect when administered orally to baby rabbits. Enterotoxic preparations of a strain of $\mathrm{K}^{12 \mathrm{~F}^{-}}$harbouring an Ent plasmid belonging to a porcine strain, of a selection of wild human and porcine enteropathogenic strains and of $V$. cholerae were included for comparison. Antiserum-neutralisation tests were also performed, particularly as Gyles and Barnum (1969) had demonstrated, in ligated intestine studies, an immunological relationship between the enterotoxins of $V$. cholerae and of porcine enteropathogenic strains of $E$. coli.

\section{MATERIALS AND METHODS}

Description of strains of Escherichia coli. The human enteropathogenic strains were given the prefix $\mathrm{H}$ and the porcine ones the prefix $\mathrm{P}$. The strain designated $\mathrm{K}^{2} \mathrm{~F}^{-}(\mathrm{H} 19) \mathrm{Ent}^{+}$was the $\mathrm{K}_{12} \mathrm{~F}^{-}$strain into which Smith and Linggood had introduced an Ent plasmid from the human enteropathogen $\mathrm{H} 19$ (antigenic structure O26:K60:H19). The K12F-(P307)Ent ${ }^{+}$ strain had been prepared in a similar manner by Smith and Gyles (1970a), its Ent plasmid having originated in the porcine enteropathogen P307 (antigenic structure O8:K87,88ab).

Preparation of $L T$ and $S T$ forms of E. coli enterotoxin. Since the enterotoxin of some

Received 30 Oct. 1971; accepted 7 Dec. 1971.

J. MED. MICROBIOL.-VOL. 5 (1972) 
enteropathogenic strains exist in two forms, ST and LT, in culture media, both forms were studied in the present work, but greater emphasis was placed on the LT form because it is more active than ST on ligated rabbit intestine (Smith and Gyles, 1970b). They were prepared according to the methods of Smith and Gyles (1970a).

$E$. coli antisera. These were prepared by the technique of Smith and Gyles (1970a).

\section{TABLE I}

The production of diarrhoea in baby rabbits by the oral administration of LT-type enterotoxin of strains of Escherichia coli

\begin{tabular}{|c|c|c|c|}
\hline $\begin{array}{l}\text { Strain from which } \\
\text { LT was prepared }\end{array}$ & $\begin{array}{l}\text { Antigenic } \\
\text { structure }\end{array}$ & $\begin{array}{l}\text { Dose } \\
(\mathrm{ml})\end{array}$ & $\begin{array}{l}\text { Number of rabbits } \\
\text { that developed } \\
\text { diarrhoea/number } \\
\text { challenged }\end{array}$ \\
\hline $\begin{array}{l}\text { K12F-(H19)Ent }{ }^{+} \\
\text {K12F-(H19)Ent } \\
\text { K12F-(P307)Ent }{ }^{+} \\
\text {K12F-(P307)Ent } \\
\text { K12 } \\
\text { K12 } \\
\text { K12 }\end{array}$ & $\begin{array}{l}? \\
? \\
? \\
? \\
? \\
?\end{array}$ & $\begin{array}{c}5 \\
20^{*} \\
5 \\
2 \cdot 5 \\
5 \\
20^{*}\end{array}$ & $\begin{array}{l}0 / 10 \\
6 / 8 \\
10 / 10 \\
2 / 2 \\
0 / 7 \\
0 / 7\end{array}$ \\
\hline $\begin{array}{l}\text { Human enteropathogens } \\
\text { H4 } \\
\text { H6 } \\
\text { H7 } \\
\text { H8 } \\
\text { H12 } \\
\text { H19 } \\
\text { H26 }\end{array}$ & $\begin{array}{l}\text { O55:K59:H7 } \\
\text { O26:K } 60: H 11 \\
\text { O111:K58:H2 } \\
\text { O119:K69:H6 } \\
\text { O128:K67:H2 } \\
\text { O26:K60:H11 } \\
\text { O125:K70:H21 }\end{array}$ & $\begin{array}{l}5 \\
5 \\
5 \\
5 \\
5 \\
5 \\
5\end{array}$ & $\begin{array}{l}0 / 1 \\
0 / 1 \\
0 / 2 \\
0 / 1 \\
0 / 1 \\
0 / 3 \\
0 / 1\end{array}$ \\
\hline $\begin{array}{l}\text { Porcine enteropathogens } \\
\text { P5 } \\
\text { P14 } \\
\text { P115 } \\
\text { P120 }\end{array}$ & $\begin{array}{l}\text { O141:K85ab,88ab } \\
\text { O147:K89,88ac } \\
\text { O149:K91,88ac } \\
\text { O138:K81,88ac }\end{array}$ & $\begin{array}{l}5 \\
5 \\
5 \\
5\end{array}$ & $\begin{array}{l}1 / 1 \\
1 / 1 \\
1 / 1 \\
1 / 1\end{array}$ \\
\hline
\end{tabular}

* Concentrated to $5 \mathrm{ml}$, by dialysis against polyvinyl-pyrrolidone, before administration.

$\mathrm{K}_{12} \mathrm{~F}^{-}(\mathrm{P} 307) \mathrm{Ent}^{+}$is a K12F $\mathrm{F}^{-}$strain to which the Ent plasmid has been transmitted from the porcine enteropathogen P307 (antigenic structure $08: \mathrm{K} 87,88 \mathrm{ab}$ ); $\mathrm{K}_{12} \mathrm{~F}^{-}(\mathrm{H} 19) \mathrm{Ent}^{+}$is a similar strain except that its Ent plasmid originated in the human enteropathogen H19.

Vibrio cholerae enterotoxin and antiserum. These were kindly supplied by the Wellcome Research Foundation, the enterotoxin consisting essentially of a freeze-dried cell-free broth culture of $V$. cholerae. For use, this was dissolved in distilled water to give a final concentration of $50 \mathrm{mg}$ per $\mathrm{ml}$. The antisera had been made by injecting the enterotoxic preparation into rabbits.

The administration of enterotoxin to baby rabbits. Rabbits, 6-9 days old and weighing approximately $100 \mathrm{~g}$, were removed from their mothers in turn and given, by means of a polythene stomach tube attached to a syringe, the preparation under test. Administration occupied only $\frac{1}{2}-1 \mathrm{~min}$., after which each rabbit was returned to its mother. The rabbits were then examined frequently for evidence of diarrhoea. In antiserum-neutralisation tests, the enterotoxin-antiserum mixtures were held at $37^{\circ} \mathrm{C}$ for $1 \mathrm{hr}$ before being given to the rabbits. The volume of $E$. coli and $V$. cholerae preparations used in these tests was 5 and $1 \mathrm{ml}$ respectively.

Rabbit ligated intestine preparations. The technique of Smith and Gyles (1970b) was employed. 


\section{RESULTS}

The results of giving baby rabbits orally LT preparations of $E$. coli $\mathrm{K}_{12 \mathrm{~F}^{-}}$(H19)Ent ${ }^{+},{\mathrm{K} 12 \mathrm{~F}^{-}}^{-}(\mathrm{P} 307) \mathrm{Ent}^{+}\left({\mathrm{K} 12 \mathrm{~F}^{-}}^{-}\right.$strains to which had been transmitted the Ent plasmids respectively from the human enteropathogenic strain, H19, and from the porcine enteropathogenic strain, P307), and of the original $\mathrm{K}_{12} \mathrm{~F}^{-}$strain, are illustrated in table I. Results are also given for

TABLE II

The neutralisation of the diarrhoea-producing effect in baby rabbits of Vibrio cholerae and Escherichia coli $\mathrm{K}^{2} \mathrm{~F}^{-}(\mathrm{P} 307)$ Ent $^{+}$enterotoxins by different antisera

\begin{tabular}{|c|c|c|c|}
\hline \multirow[t]{2}{*}{$\begin{array}{l}\text { Strain against which } \\
\text { antiserum was prepared }\end{array}$} & \multirow{2}{*}{$\begin{array}{l}\text { Dose of } \\
\text { antiserum } \\
\text { (ml) }\end{array}$} & \multicolumn{2}{|c|}{$\begin{array}{l}\text { Number of rabbits that developed } \\
\text { diarrhoea/number challenged, when } \\
\text { the antiserum was pre-incubated with } \\
\text { the enterotoxin of }\end{array}$} \\
\hline & & V. cholerae & K12F-(P307)Ent ${ }^{+}$ \\
\hline V. cholerae & $\begin{array}{l}2 \cdot 0 \\
1 \cdot 0 \\
0 \cdot 5 \\
0 \cdot 25 \\
0 \cdot 125\end{array}$ & $\begin{array}{l}0 / 1 \\
0 / 1 \\
0 / 1 \\
0 / 1 \\
0 / 2\end{array}$ & $\begin{array}{l}0 / 3 \\
2 / 2 \\
1 / 1 \\
\cdots \\
\cdots\end{array}$ \\
\hline $\mathrm{K} 12 \mathrm{~F}^{-}(\mathrm{P} 307) \mathrm{Ent}^{+}$ & $\begin{array}{l}2.0 \\
1.0 \\
0.5\end{array}$ & $\begin{array}{l}1 / 3 \\
1 / 1 \\
1 / 1\end{array}$ & $\begin{array}{l}\dddot{0} / 3 \\
1 / 4\end{array}$ \\
\hline $\mathrm{K}_{12 \mathrm{~F}^{-}}(\mathrm{H} 19) \mathrm{Ent}^{+}$ & $\begin{array}{l}2 \cdot 0 \\
1 \cdot 0\end{array}$ & $\begin{array}{l}1 / 1 \\
\cdots\end{array}$ & $\begin{array}{l}1 / 1 \\
2 / 2\end{array}$ \\
\hline None* & $2 \cdot 0$ & $1 / 1$ & $2 / 2$ \\
\hline
\end{tabular}

$*$ None $=$ normal pig serum.

The dose of $V$. cholerae and $\mathrm{K}_{12} \mathrm{~F}^{-}(\mathrm{P} 307) \mathrm{Ent}^{+}$enterotoxins employed was 1 and $5 \mathrm{ml}$ respectively.

several wild enteropathogenic strains of human and porcine origin. The human strains had been specially selected in that they had previously yielded LT preparations that consistently dilated ligated rabbit intestine; the porcine strains were all strongly positive in this respect (Smith and Gyles, 1970b).

None of the ten rabbits given $5 \mathrm{ml}$ doses of LT prepared from $\mathrm{K}_{12} \mathrm{~F}^{-}(\mathrm{H} 19) \mathrm{Ent}^{+}$or from the seven human enteropathogenic strains, including H19 itself, showed any sign of ill-health as a result. Six of eight given $20 \mathrm{ml}$ of the LT of $\mathrm{K}^{2} 2 \mathrm{~F}^{-}$(H19)Ent ${ }^{+}$that had been concentrated to $5 \mathrm{ml}$ by dialysis against polyvinyl-pyrrolidone developed diarrhoea $10-18 \mathrm{hr}$ after administration, the principal abnormality noted when they were killed being gross distention of the large intestine with a pale yellow watery fluid (fig. 1).

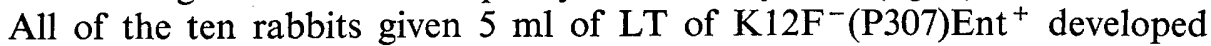
severe diarrhoea within 4 to $9 \mathrm{hr}$, nine of them dying within $8 \frac{1}{2}$ to $20 \mathrm{hr}$. Apart from the diarrhoea, the most important clinical sign in these rabbits was intense dehydration. At autopsy, many of them had large amounts of watery 
fluid in the small intestine as well as in the large intestine (fig. 2). Similar findings were obtained in the rabbits given LT prepared from the wild porcine enteropathogenic strains. No sign of ill-health was noted in baby rabbits given ST,

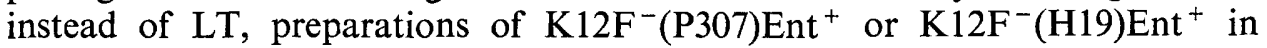
15-ml amounts.

All four baby rabbits given $1 \mathrm{ml}$ of the enterotoxic preparation of $V$. cholerae developed severe diarrhoea 6 to $12 \mathrm{hr}$ later, the clinical and post-mortem signs closely resembling those observed in the rabbits given the LT preparations of porcine enteropathogenic $E$. coli. None of three rabbits given $0.5 \mathrm{ml}$ of the $V$. cholerae preparation developed diarrhoea.

The dilating effect of $\mathrm{LT}$ preparations of $\mathrm{K}_{12} \mathrm{~F}^{-}(\mathrm{H} 19) \mathrm{Ent}^{+}$and

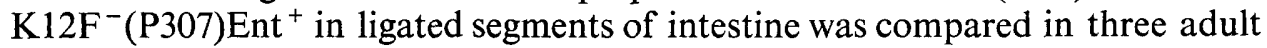
rabbits. Approximately four times the amount of the $\mathrm{K}_{12} \mathrm{~F}^{-}(\mathrm{H} 19) \mathrm{Ent}^{+} \mathrm{LT}$ preparation was required to produce the same degree of dilatation as that

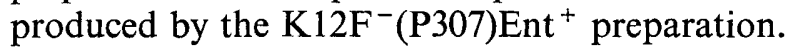

The results of studies on the diarrhoea-inhibiting effect of different antisera

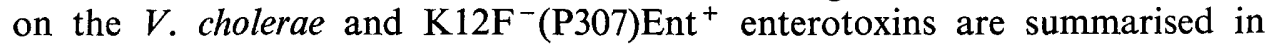
table II. Although both enterotoxins were neutralised by either the $V$. cholerae

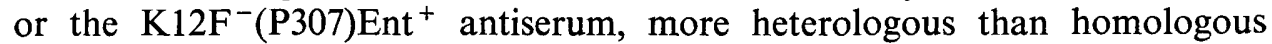
antiserum was required in each case to achieve this neutralisation. The ${\mathrm{K} 12 \mathrm{~F}^{-} \text {(H19)Ent }}^{+}$antiserum and normal pig serum had no observable neutralising effect on these two enterotoxic preparations.

\section{Discussion}

Because they were made in exactly the same manner, the only important difference between the LT preparations of $\mathrm{K}_{12 \mathrm{~F}^{-}}(\mathrm{H} 19) \mathrm{Ent}^{+}$and $\mathrm{K}^{12 \mathrm{~F}^{-}}$(P307) $\mathrm{Ent}^{+}$lies apparently in the fact that they represent the expression of two different Ent plasmids, one derived from a human enteropathogenic strain of Escherichia coli and one from a porcine one. The results indicate that the "porcine" plasmid codes for a more powerful enterotoxin for rabbits, shown by the production of diarrhoea in baby rabbits and by the dilatation of ligated intestinal segments of adult rabbits. Furthermore, the tests with the wild human and porcine strains suggest that this difference is a general one.

The antiserum-neutralisation experiments lend some support to the observation of Gyles and Barnum (1969) in ligated intestine tests that the enterotoxins of $V$. cholerae and porcine enteropathogenic $E$. coli are immunologically related. The quantitative aspects of our experiments, however, suggest that they are not identical.

\section{SUMMARY}

Strains of Escherichia coli $\mathrm{K} 12 \mathrm{~F}^{-}$to which Ent plasmids from a human and a porcine enteropathogenic strain of $E$. coli had been transmitted yielded cellfree preparations that produced diarrhoea when administered orally to baby rabbits. The preparations obtained from the strain containing the "porcine" plasmid was more active in this respect than were those of the strain containing the "human" plasmid. This difference was also observed when preparations 


\section{COLI AND CHOLERA ENTEROTOXINS}

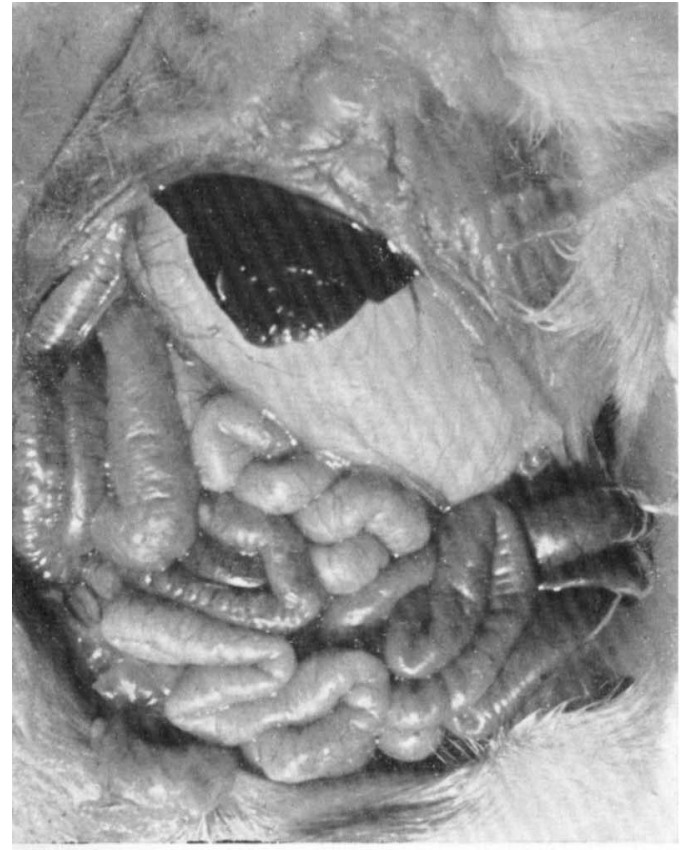

FIG. $1 a$.

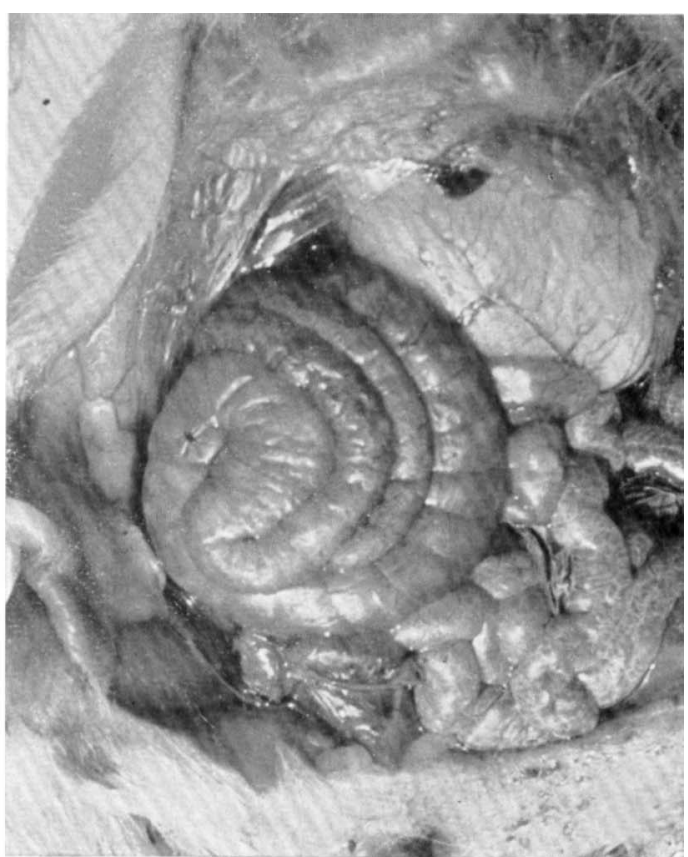

FIG. $1 b$.

FIG. 1.- The baby rabbit on the right had been given, $24 \mathrm{hr}$ previously, $20 \mathrm{ml}$ of an LT preparation of $E$. coli $\mathrm{K}_{12} \mathrm{~F}^{-}(\mathrm{H} 19) \mathrm{Ent}^{+}$concentrated by dialysis against polyvinyl-pyrrolidone to $5 \mathrm{ml}$ before administration. The one on the left had been given a similar preparation of $\mathrm{K}_{12} 2 \mathrm{~F}^{-}$at the same time. About $\times 3$.

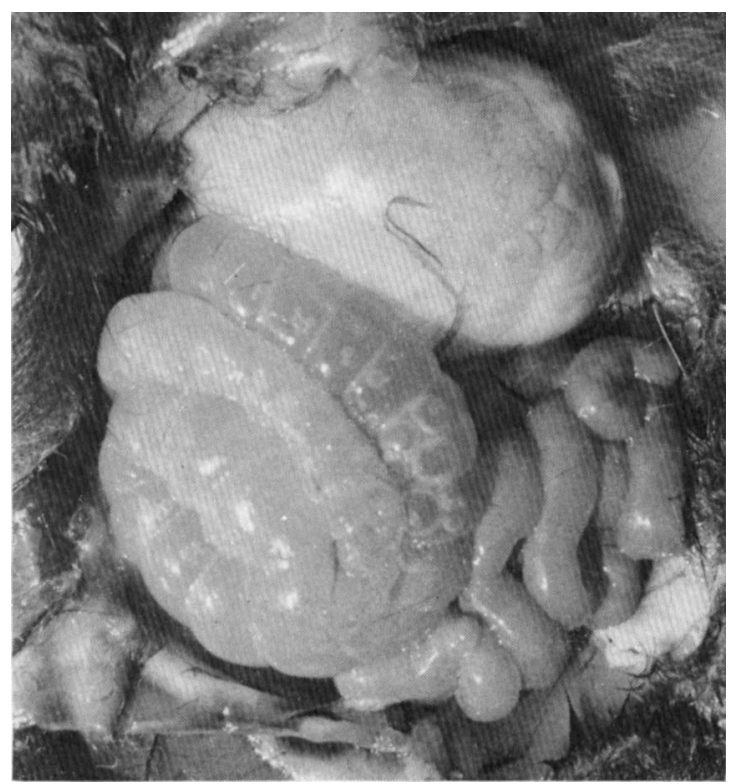

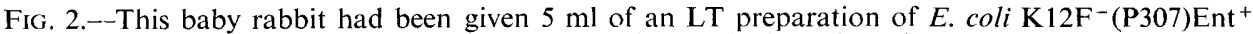
$20 \mathrm{hr}$ previously. The small intestine in addition to the large intestine contained large amounts of watery fluid. About $\times 2 \cdot 5$. 
of wild human and porcine enteropathogenic strains were compared. The diarrhoea produced in the baby rabbits resembled that produced by Vibrio cholerae enterotoxin.

The diarrhoea-producing activity of cell-free preparations of the K12 strain that contained the " porcine" Ent plasmid could be neutralised by antiserum against either this strain or $V$. cholerae; so could cell-free preparations of $V$. cholerae, but more heterologous than homologous antiserum was required in each case to achieve neutralisation.

I am grateful to Miss Carole Smith for her capable technical help and to Dr P. D. Walker of the Wellcome Foundation for the $V$. cholerae enterotoxin and antiserum.

\section{REFERENCES}

Dutta, N. K., Panse, M. V., And Kulkarni, D. R. 1959. Role of cholera toxin in experimental cholera. J. Bact., 78, 594.

Gyles, C. L., AND BARnum, D. A. 1969. A heat-labile enterotoxin from strains of Escherichia coli enteropathogenic for pigs. J. Infect. Dis., 120, 419.

KOHLER, E. M. 1968. Enterotoxin activity of filtrates of Escherichia coli in young pigs. Amer. J. Vet. Res., 29, 2263.

Smith, H. W., AND Gyles, C. L. 1970a. The relationship between two apparently different enterotoxins produced by enteropathogenic strains of Escherichia coli of porcine origin. J. Med. Microbiol., 3, 387.

Smith, H. W., AND GyLES, C. L. 1970b. The effect of cell-free fluids prepared from cultures of human and animal enteropathogenic strains of Escherichia coli on ligated intestinal segments of rabbits and pigs. J. Med. Microbiol., 3, 403.

Smith, H. W., AND Halls, Sheila 1968. The transmissible nature of the genetic factor in Escherichia coli that controls enterotoxin production. J. Gen. Microbiol., 52, 318.

SMITH, H. W., AND LingGoOd, MARGARET A. 1971. The transmissible nature of enterotoxin production in a human enteropathogenic strain of Escherichia coli. J. Med. Microbiol. 4, 301 . 